\title{
ДО ПИТАННЯ ЩОДО ПРИНЦИПВ СПАДКОВОГО ПРАВА
}

\author{
ЧУЙКОВА Валентина Юрї̈вна - кандидат юридичних наук,доцент кафедри \\ цивільного права №2 Національного юридичного університету імені Ярослава \\ Мудрого, м.Харків
}

DOI:10.32782/LAW.2019.3.28

В статье содержится краткий анализ правовой природъ приниипов наследственного права. В юридической литературе вопрос о приниипах наследственного права рассматривается по-разному, существуют различнъге подходъ к их определению. Указанные приниипъ базируются на бундаментальнъих отраслевъгх принципах гражданского права.

Ключевъе слова: приницип права; принициь наследственного права; наследственнъе правоотношения.

"Установление или выведение принципов отрасли права помогает правильнее применять нормы данной отрасли, лучше понимать ее сущность и социальное значение,"- писав видатний цивіліст Братусь С.М. [2,с.13].

Юридична наука, в тому числі і цивілістична, приділяла певну увагу дослідженню принципів права, приведенню їх у певну систему, розробці на цій основі рекомендацій, які мають сприяти удосконаленню законодавства та практики його застосування. Практична сторона цього питання обумовлена тим, що в умовах свободи суб'єктів економічних відносин, яка поступово збільшується, своєчасне правове врегулювання їх поведінки стає необхідністю.

Спадкове право, як ніяка інша підгалузь цивільного права, внаслідок прийняття Цивільного кодексу 2003 року піддалося суттєвим змінам. Досягненням останньої реформи спадкового права стало те, що норми Книги шостої Цивільного кодексу Укра- їни (далі - ГК України) значно розвинули і конкретизували положення попереднього ЦК України 1963 року. Якщо раніше проблеми, які виникали у судовій та нотаріальній практиці, були викликані проблемами у законодавстві, доводилося вирішувати за допомогою роз'яснень Пленуму Верховного Суду України або виводити те або інше положення, виходячи з сенсу і духу закону, то зараз відповіді на багато питань можна знайти вже безпосередньо в нормах кодифікованого акту українського цивільного законодавства.

Окремі принципи регулювання окремих спадкових відносин збереглися. Законодавець при створенні окремих норм застосував радикальні зміни, в тому числі , заборонив перехід особистих немайнових прав ( ч.1 п.1 ст.1219 ЦК України), дозволив заповіти, укладені у простій письмовій формі (ст.1249 ЦК України), звів до мінімуму випадки переходу майна державі від померлого шляхом розширення кола спадкоєм-

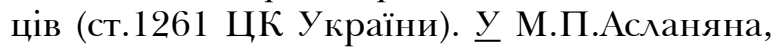
С.М.Братуся, Б.С.Антімонова, К.О.Граве, М.В. Гордона, В.К.Дронікова, А.М.Нємкова, П.С.Нікітюка, Ю.К.Толстого, С.Я.Фурси та E.I.Фурси проблеми принципів спадкового права не знайшли достатнього аналізу, тому це питання недостатньо опрацьоване в цивілістичній науці. А між тим, запропонована різними фахівцями система та зміст принципів спадкового права не могла не відображати якісні особливості розвитку певного типу права. Спадкове право тісно 
пов'язане із правом власності, тому невипадково спадкування набуває особливого характеру, значення і форми в різні історичні епохи, оскільки право спадкування не може не бути тісно пов'язаним зі змінами виробничих відносин у різних суспільно економічних формаціях.

Основи соціалістичного спадкового права було закладено Декретом ВЦВК РФСР від 27 квітня 1918р. «Про скасування спадкування». В Україні аналогами цього нормативного акта були декрет РНК України від 11 березня 1919p. «Про скасування спадкування» та Декрет РНК України від 21 березня 1919р. «Про скасування спадкування».

Визначаючи основні принципи радянського спадкового права, які випливали із Декрету від 27 квітня 1918р., можна назвати такі:

1) право спадкування набувають лише особи, які були тісно пов'язані зі спадкодавцем за його життя;

2) за подружжям визнається право спадкування на тих самих підставах, що і за дітьми;

3) принцип рівності спадкоємців незалежно від статі;

4) уніфікація регулювання спадкових правовідносин, які виникали у зв'язку зі смертю члена колгоспного двору і внаслідок смерті члена сім’ї в місті;

5) трудовий характер майнового правонаступництва після смерті громадянина.

Вперше змістовно систему принципів спадкового права у радянській юридичній літературі спробував сформувати А.М.Нємков, який навів шість, на його думку, основних принципів : 1) використання спадкового майна для забезпечення непрацездатних родичів і подружжя померлого; 2) визнання права спадкування за законом на предмети домашньої обстановки і вжитку за спадкоємцями, які мали господарсько - трудовий зв'язок з цим майном; 3) визнання права на спадкування за законом за найближчими спадкодавцеві особами; 4) принцип свободи заповіту; 5) принцип повної рівності подружжя; 6)принцип рівності спадкових часток при спадкуванні за законом [4, с.86].

П.С.Нікітюк вважав, що 3 наведених принципів такими, що стосуються спадко- вого права, можна вважати лише положення про визнання права на спадкування за найбільш близькими до спадкодавця особами. Наприклад, немає підстав відносити до принципів спадкового права свободу заповіту. Свою позицію він обгрунтовує тим, що на початку становлення радянського спадкового права складання заповіту на користь сторонніх осіб взагалі не допускалося. Свобода ж заповіту, яку розуміють як можливість скласти заповіт, не враховуючи інтереси непрацездатних членів сім’і, - “не та правова ідея, яка визначає характер правового регулювання спадкування"[5,c.163]. Відповідно, немає підстав зводити свободу заповіту в ранг принципу спадкового права.

Серед сучасних цивілістів немає єдності 3 питання щодо кількості і найменування принципів спадкового права. Це пояснюється недостатністю теоретичних розробок критеріїв віднесення правових норм до принципів спадкового права, з одного боку, та недосконалістю спадкового законодавства, з іншого.

Думки науковців не збігаються і стосовно кола принципів, які становлять систему спадкового права. Деякі фахівці безмежно розширюють їх число, інші не визнають традиційних принципів.

Ю.К. Толстой серед галузевих принципів спадкового права, як підгалузі цивільного права, наводить такі :

- універсальність спадкового правонаступництва,

- свобода заповіту,

- забезпечення прав та інтересів необхідних спадкоємців,

- урахування не лише дійсної волі спадкодавця, а і припустимої,

- свобода вибору у спадкоємців, які закликані до спадкування,

- охорона основ правопорядку і мораᄉi,

- інтереси спадкодавця, спадкоємців, інших фізичних та юридичних осіб щодо спадкування,

- охорона самої спадщини від будьяких протиправних чи аморальних посягань[7,с.164] .

На принципово інших засадах будує свою концепцію принципів спадкового 


\section{Дискусії, обговорення, актуально}

права С.П.Гришаєв. За його твердженням, спадкове право базується на співвідношенні двох основних принципів : свободи спадкування та охорони інтересів і так званих обов’язкових спадкоємців. Серед додаткових принципів він наводить принцип правонаступництва і принцип охорони спадщини від протиправних посягань [3, с.9-10].

Отже, в юридичній літературі запропоновані різноманітні класифікації принципів спадкового. Певною мірою ці поділи залежали від тієї мети, яку ставили перед собою дослідники.

Як слушно зазначав С.M. Братусь, правовий принцип не можна змішувати із правовим інститутом як сукупністю норм, що регулюють певну групу суспільних відносин у середині того їх виду, який становить предмет даної галузі права [2,с.29].

Принципи спадкового права як підгалузі цивільного права повинні мати специфічні ознаки, а саме:

- відповідати певній суспільно - політичній формації,

- дістати відображення у правових приписах, відображення в реальних і конкретних правових нормах, які без нього існувати не можуть. Кожна суспільно - економічна формація, змінюючи основні правові засади регулювання суспільних відносин, формує свою, відмінну від попередньої, систему галузевих і внутрішньогалузевих принципів,

- мати певну стабільність, постійність i визначати фактичний стан і перспективи розвитку спадкового права,

- містити в собі чіткі ідеї, в яких підсумовуються головні теоретичні положення спадкового права і важливі вказівки для органів нотаріату та судочинства,

- мати можливість знайти своє вираження в будь - яких спадкових відносинах (з урахуванням їх специфіки).

Система принципів спадкового права становить сукупність таких загальних засад, на яких здійснюється спадкування :

1. Свобода волевиявлення спадкодавия $i$ спадкоємщів. Цей принцип тісно пов'язаний iз загальноцивільним принципом диспозитивності цивільно-правового регулювання і означає, що правоздатний спадкодавець у будь - який час має можливість скласти заповіт на все майно чи його певну частку, змінити заповіт чи скасувати або не складати заповіт взагалі. Реалізуючи право на заповіт, заповідач має можливість заповідати майно будь - яким особам, на свій розсуд визначити частки спадкоємців у спадщині, позбавити спадщини одного, кількох чи всіх спадкоємців за законом, не зазначаючи причин такого позбавлення, а також включити до заповіту інші розпорядження, передбачені ст.1235 ЦК України.

Заповідач має право заповідати майно не тільки особам, які належать до числа спадкоємців за законом , а й сторонній особі, яка не перебуває із заповідачем у родинних, сімейних відносинах, а також юридичній особі, державі Україна, територіальній громаді, іноземній державі та іншим суб'єктам публічного права (ст.2 ЦК України). Зокрема, заповідач може залишити своє майно спадкоємцю другої черги, незважаючи на наявність осіб, які належать до першої черги спадкоємців за законом, тобто він не зв'язаний ні колом спадкоємців за законом, ні черговістю їх закликання до спадкування.

Це положення є головним принципом спадкового права. Принцип свободи волевиявлення спадкодавця закріплено у ст.ст. 1234-1237, 1240,1242-1244,1246,1254,1302, 1308 ЦК України.

Спадкоємцю, у свою чергу, надано право прийняти спадщину або відмовитися від неї.

2. Універсальність спадкового правонаступництва. Суть цього принципу полягає в тому, що акт прийняття спадщини поширюється на всю спадщину,де б вона не була і в чому $б$ не полягала, складалася б винятково 3 прав чи лише з обов'язків. Спадщина не може бути прийнята частково. Тому спадкоємець, який прийняв частину спадщини, вважається таким, що прийняв усю спадщину.

У ст.ст. 1218-1219 ЦК України законодавець визначає склад спадщини. Спадкоємці набувають усіх прав та обов'язків, які належали спадкодавцеві на момент відкриття спадщини і не припинилися внаслідок його смерті. Особливості спадкування окремих видів майна (право на одержання сум заро- 
бітної плати, пенсії, стипендії, аліментів, інших соціальних виплат, які належали спадкодавцеві) визначено в ст. 1227 ЦК України та окремих підзаконних актах, наприклад, у відповідній інструкції МВС України, яка визначає порядок спадкування мисливської зброї, спеціальних засобів тощо. Спадщина не приймається по частках. Єдиним винятком 3 цього правила є можливість спадкоємця відмовитися від обов'язків правонаступника за договором довічного утримання (ст.757 ЦК України).

Від універсального правонаступництва відрізняють правонаступництво сингулярне, при якому до спадкоємця переходить не сукупність прав і обов'язків спадкодавця, а лише певні його права (або обов'язки). Наприклад, якщо за заповітом спадкодавець поклав на спадкоємця обов'язок передати яку-небудь з отриманих у спадщину речей у користування третій особі, то ця третя особа буде сингулярним правонаступником і до того ж одержить відповідні права не безпосередньо від спадкодавця, а через спадкоємця.

3. Приници послідовності закликання до спадщини при спадкуванні за законом. Переважне право розподілити спадщину надано спадкодавцеві; якщо ж він своїм правом не скористався, то законодавець закликає до спадкування спадкоємців послідовно в порядку черг, причому спадкоємці другої черги можуть набути спадщину лише за умови відсутності спадкоємців першої черги.

Суть цього принципу, який закріплено і ст.1258 ЦК України, полягає в тому, що кожна наступна черга спадкоємців за законом набуває право на спадщину лише у разі відсутності спадкоємців попередньої черги, усунення їх від права на спадкування, неприйняття ними спадщини або відмови від iii прийняття. Aле в той же час, ст.1259 ЦК України надає право спадкоємцям за законом змінювати встановлену ЦК черговість спадкування. Так, після відкриття спадщини спадкоємці можуть змінити черговість спадкування шляхом складання договору, відповідно до якого одночасно із їх чергою буде спадкувати спадкоємець іншої черги, що не закликається до спадкування. Такий договір має бути нотаріально посвідченим. Він не може порушувати прав спадкоємця, який не бере у ньому участі, а також спадкоємця, що має право на обов'язкову частку (ст.1241 ЦК України).

Iз загального правила виняток може зробити лише суд у випадку, який передбачений ч.2 ст. 1259 ЦК України. За позовом особи, що є спадкоємцем за законом наступної черги, суд може визнати за нею право на спадкування разом зі спадкоємцями тієї черги, яка має право на спадкування, якщо буде встановлено, що протягом тривалого часу вона опікувалася, матеріально забезпечувала, надавала іншу допомогу спадкодавцеві, який через похилий вік, тяжку хворобу або каліцтво був у безпорадному стані.

4. Принцип рівності спадкових часток при спадкуванні за законом. Незалежно від віку, статі, родинних чи сімейних зв'язків, соціального становища спадкоємці однієї черги отримують спадщину у рівних частках.

Це положення дістало відображення у ст.1267 ЦК України, в якій закріплено правило що частки у спадщині кожного із спадкоємців є рівними. Виняток $з$ цього правила має місце при спадкуванні спадкоємцями,які закликаються до спадкування за правом представлення.

5. Державно - правовий захист непрацездатних родичів $і$ иленів сім'і спадкодавия. Суть цього принципу полягає в тому, що спадкування серед інших виконує і соціально - забезпечувальну функцію. Ще за часів Римської імперії держава надавала захист близьким родичам спадкодавця, яких без достатніх на те підстав заповідач при складанні заповіту позбавляв спадщини. Такі спадкоємці мали право звернутися 3 позовом про оспорювання заповіту та вимагати належної їм частки спадщини.

Вітчизняний законодавець і в ЦК УРСР 1922p., і в ЦК УРСР 1963р., і в ЦК України 2003р. послідовно захищав і захищає інтереси так званих обов'язкових спадкоємців.

Змінювалося коло осіб, які мали право на обов'язкову частку, розмір обов'язкової частки, але загальна тенденція була чітко спрямована на захист майнових інтересів неповнолітніх і непрацездатних осіб, про яких спадкодавець за своє життя повинен був піклуватися. Це дає підстави розглядати положення, що дістали закріплення в 


\section{Дискусії, обговорення, актуально}

ст.1241 ЦК України, як форму вираження принципу підгалузевого законодавства.

Саме в цьому принципі втілено соціально - забезпечувальну функцію спадкування. Держава ніколи не погодиться з тим, щоб за наявності спадкового майна заповідача, особи, яких спадкодавець утримував чи повинен був утримувати за своє життя, залишилися без допомоги після його смерті.

Цей принцип перебуває в єдності з попереднім, вони урівноважують один одного, а визначення їх оптимального співвідношення $є$ важливим завданням законодавця.

6. Приниип сімейно - родинного характеру спадкування. Коло спадкоємців за законом визначає законодавець залежно від ступеня кровного споріднення та сімейних відносин.

7. Приниип матеріально-забезпечувального призначення спадкування. Вже сама назва принципу виражає його суть: ціль переходу прав та обов'язків від спадкодавця до спадкоємців забезпечує задоволення матеріальних інтересів спадкоємців і кредиторів спадкодавця. I навіть те, що згідно зі ст.1231 ЦК України спадкоємець, який прийняв спадщину, відповідає за боргами спадкодавця, не ставить його у невигідне та скрутне становище, оскільки відповідно до цієї статті така відповідальність спадкоємця обмежується розміром дійсної вартості спадкового майна.

Кирилова О.С. визначає охоронні принципи спадкового права, які включають у себе два принципи. Перший надає охорону: засад правопорядку і доброчесності; інтересів спадкодавця і спадкоємців; інтересів інших фізичних та юридичних осіб.

Проявом цього принципу $є$ усунення негідних спадкоємців, захист таємниці заповіту, виконання заповідальних розпоряджень тощо.

Другий принцип полягає в охороні спадщини від посягань. Відповідно 3 цим принципом норми закону забезпечують: розділ спадкового майна відповідно заповіту або закону; охорону і управління спадщиною; відшкодування витрат на охорону та управління майном [6, с.122].

Саме на цих основних засадах і відбувається регулювання спадкових відносин.
Від принципів спадкового права як підгалузі цивільного законодавства необхідно відрізняти його так звані функціональні положення, які не відіграють самостійної ролі, а лише сприяють належній реалізації спадкових прав. До них відносяться принципи таємниці заповіту, охорони спадкового майна, відшкодування витрат особам, які здійснювали догляд за спадкодавцем чи зазнали витрат у зв'язку з його похованням тощо.

Важливого значення набуває використання підгалузевих принципів у правотворчій діяльності, особливо в умовах постійного розширення масиву підзаконних нормативних актів, збільшення кількості правових приписів. Не можна не погодитися з тезою, що правовий принцип містить набагато більше інформації, ніж конкретна і багатослівно виражена норма.

Приймаючи нормативний акт, законодавець повинен враховувати загальні засади, на яких побудовано систему норм галузі чи підгалузі права, що дасть змогу уникнути декларативності, невизначеності, казуїстичності.

Таким чином, під принципами спадкового права розуміють керівні ідеї, основоположні вимоги, відправні установлення, вихідні начала, які виражають об'єктивні закономірності, тендениї $i$ потреби суспільного розвитку, визначають зміст норм спадкового права, ї̈ місие, роль і призначення в системі права, мають важливе значення для побудови нормативної основи иүєї підгалузі та п̈̈ застосування.

Учені - цивілісти не мають єдиної думки щодо визначення цих принципів, їх класифікації, але, узагальнивши праці провідних науковців сучасності, можна виділити такі основні принципи спадкового права, як : свобода волевиявлення спадкодавця i спадкоємця; універсальність спадкового правонаступництва; принцип послідовності закликання до спадкування за законом; принцип рівності спадкових часток при спадкуванні за законом; державно - правовий захист непрацездатних родичів і членів сім'ї заповідача; принцип сімейно - родинного характеру спадкування; принцип матеріально-забезпечувального призначення спадкування.

Правильне застосування конкретних норм спадкового законодавства можливе 
лише за умови врахування загальних принципів цивільного права.

Наведені засади спадкового права є принципами приватного права, але це не виключає наявності публічних інтересів. У стабільності інституту спадкового права зацікавлені не лише громадяни, а й держава в цілому, оскільки приватні інтереси в цьому випадку тісно пов'язані із мораллю суспільства і безпекою держави.

Принципи спадкового права як підгалузі права повинні мати своє чітке місце в ієрархії принципів цивільного права і вітчизняного права взагалі. Правильне застосування конкретних норм спадкового законодавства можливе лише за умови врахування загальних принципів цієї підгалузі цивільного законодавства.

Якими 6 відмінними за конкретним змістом не були норми спадкового права, їх об'єднують загальні засади, на яких побудовано систему спадкового права.

Система принципів не може бути незмінною і аморфною. Вона динамічно реагує на зміни. Принципи підгалузей права застосовують у разі, якщо виникає прогалина у чинному законодавстві, що обумовлює необхідність застосування аналогії права. Суд не може відмовити позивачеві у захисті порушеного права, посилаючись на вади конкретної норми, яка дала 6 змогу розглянути справу по суті. Тому саме в цьому випадку виникає необхідність обгрунтувати прийняте рішення по справі відповідно до загальних засад законодавства.

Досліджені принципи спадкового права закріплено в галузевому та підгалузевому законодавстві, що свідчить про їх регламентацію і прояв у законодавстві, які, у свою чергу, зумовлені політичними і економічними змінами в суспільстві.

\section{Література}

1. Цивільний Кодекс України.- К.: Алерта, 2018. - 320 с.

2. Братусь С.Н. Предмет и система советского гражданського права / С.Н.Братусь.М.: Госюриздат, 1963.-198 с

3. Гришаев С.П. Наследственное право :Учебно-практ. Пособие/ С.П.Гришаев.М.:Проспект,2011.-294 с.
4. Немков А.М. Основные принципы советского наследственного права // Ученые записки Пермского ун-та.- 1965.-№129,C.109.

5. Никитюк П.С. Наследственное право и наследственный процесс.- Киши нев, Штиинца, 1973.-390 с.

6. Кириллова Е.А.Значение и роль принципов наследственного права// Вестник Пермского ун-та , вып.3(17), 2012.-С.114123.

7. Толстой Ю.К. Наследственное право.М.: 1999.- 521 с.

The practical side of nourishment of principles of recession law is enshrined in the words that, in the minds of freedom, sub's of economic vidnosin, as a matter of fact, are in good stead; Spadkova right as a civil law civil right to adopt the Civil Code of Ukraine 2003 to the law on social law. As a heir to the recession law reform, the deeds of the law were protected from the forefront of the legal system, and the establishment of the legal system of Ancient Rome, as well as of the legal systems of the major powers. Bula has a new system of principles for regulating the decline of income. Problems of the principles of law and the principles of recession are specifically addressed by the lawyers: they need to rely on the theory of law and practice to get more and more information.

Oskilki spadkove law - the okremiy institute of civil law, then the norm should be based on the deprived ones of the principles of legal rights. The prototype of the Single and Unambiguous Transition of the Principles of Decline Law in Civil Law is not applicable. The middle of nowadays civil dignity is the provision of the principles and principles of decline law. This is explained by the lack of theoretical variations of the criteria for the introduction of legal norms to the principles of decline law, on one side, and the lack of accuracy of decline legislation in general.

Dumki naukovtsiv not zbigayutsya i stosnovno stake principle, yaki to become a system of recessionary law. Acts of fakhivtsi uninterruptedly expand their number, but they don't recognize the traditional principles. 


\section{Дискусіі, обговорення, актуально}

\section{АНОТАЦІЯ}

У статті наводиться стислий аналіз правової природи принципів спадкового права. У юридичній літературі питання щодо приниипів спадкового права розглядається по-різному, існують різні підходи до їх визначення. Наведені принципи базуються на фбундаментальних галузевих приницпах ицивільного права.

Ключові слова: принципи права; принципи спадкового права; спадкові відносини.

In legal literature, it is pronounced on the recognition of the principles of decline law. The singing world was lying in the middle of the road, and the yachers set themselves before them. The system of principles of recessionary law makes it possible to acquire such obscure ambushes, in which case there is recession:

Freedom of the will of the recession and recession. It's a principle of quietly tackling the obscurely civilized principle of dispositiveness of civil law regulation, which means that rightwing people should have a good chance of being locked up.

This is the main principle of the decay law. The principle of freedom of will and recession is closed at art. 1234-1237, 1240.12421244.1246.1254.1302, 1308 of the Central Committee of Ukraine. Universality of recessionary offense of law. The essence of the principle of the poleg is that, when the act of accepting the recession is extended to the whole recession, there is no reason for it and for whatever reason it could not be stored, it would have been better for me to have more rights than anything else. Recession cannot be taken often.

The principle of post-approval is up to recession with recession beyond the law. The essence of this principle, which is secured in accordance with Article 1258 of the Central Committee of Ukraine, lies in the fact that the skin is under the protection of the devotees for the law that they have less right to be deprived of their rights for more than one day, they are more likely to have less and less accept. $T \quad h \quad e$ principle of equality of decline is frequent in decline according to law. Independently, there will be viku, stati, native chi simeynyh zviyazkiv, the social campus of the wretched one chergy, to wipe off the slaughter in the new parts.

As a rule, there was a complete image at Art. 1267 of the Central Committee of Ukraine, in most of the countries the rule is often fixed in cases of declining skin and falling. The vignettes of the whole rule are small when falling down, like falling down for the right of representation. The sovereign - the legal zahist of unprincipled relatives and members of the spa spa. The essence of the principle of the polec lies in the fact that the decline in the middle of the past and the socially safe function. In itself, in the whole principle, it is socially and securely functional. The power of nikoli could not be expected in winter, so that, for the manifestation of a recession lane, the task, individuals, some kind of recession, having reproached chi, who was guilty of utrimuvati for their life, were lost without the help of death. The principle of retirement is one in advance, that one must respect one, and the designation of the optimal resolution is an important legislative endeavor. The principle of family - native character decline. The number of people who fall behind the law is that the lawmaker has the law to fall in the first step of the blood dispute and the next vidnosin.

The principle of material-safety-related decline. Later, the very name is to the principle of the supreme turn: the whole transition is right and the need for recession to recession to the satisfaction of the material interest recession and creditors of recession. Itself on these main ambushes and viduvatsya to regulate the decline of vidnosin. Inducted in ambush law $\epsilon$ the principles of private law, but without any clues $\epsilon$ manifestations of public interest. It is more correct to concretize the specific norms of the downturn legislation.

The principle of recessionary law has been consolidated into the Galusian and the Second Galactic laws, which stipulate that they are regulated in the laws, in their own way, and are motivated by political and economic sermons in suspensions.

Key words: principles of law; principles of inheritance law; inheritance relationship. 